\title{
Monitoring of Buituri Slag Dump, Hunedoara County in Relation with Environmental Protection
}

\author{
Anca-Maria MOSCOVICI ${ }^{1 *}$, Alina Corina BALA ${ }^{1}$, Floarea Maria BREBU ${ }^{1}$, \\ Clara-Beatrice VILCEANU ${ }^{1}$ and Cosmin Ion CZEGU ${ }^{2}$ \\ ${ }^{1}$ Department of Overland Communication Ways, Foundation and Cadastral Survey. Polytechnic \\ University Timisoara, Romania. \\ ${ }^{2}$ S.C. Coneta SRL Hunedoara, Romania. \\ *)Corresponding author, e-mail: moscovicianca@gmail.com
}

BulletinUASVM Horticulture 74(1) / 2017

Print ISSN 1843-5254, Electronic ISSN 1843-5394

DOI:10.15835/buasvmcn-hort:12300

\begin{abstract}
Detailed analysis of appearance and relief evolution in mining areas cannot be done without mining engineering concepts. Over time, researchers around the world have responsibly been involved in this matter necessary for the development of society, also with obvious implications and repercussions over the quality of life. The purpose of the scientific research detailed in this paper comprises in monitoring the slag dump from Buituri, Hunedoara County using space geodetic technology. Slag dump is the result of steel production activities carried out under the steel factory Arcelor Mittal Hunedoara S.A., formerly known as the steel factory Hunedoara - Siderurgica S.A. Therefore it was decided to conduct monthly topographic measurements to monitor possible dynamic changes that may appear in the context of continuous exploitation of the above mentioned slag dump. Monitoring possible movements is performed by comparing transversal and longitudinal profiles drawn based on zero measurement carried out on 20.05.2011, with the ones obtained after processing of the monthly measurements realized throughout the years 2011, 2012, 2013, 2014, 2015 and 2016. Also, for observing the displacements, comparative charts or tables with records regarding coordinates differences are studied. The issue of measuring and graphic representation of settlements, horizontal linear movements and landslides for structures such as slag or sterile dumps, requires further studies and interdisciplinary research, creating links between specialists in the fields of terrestrial measurements science and geology.
\end{abstract}

Keywords: environmental protection, GNSS technology, monitoring, planimetric and altitudinal movements slag dump

\section{INTRODUCTION}

In mining areas cannot study the evolution of the relief without mining in engineering concepts. Therefore researchers have studied this phenomenon have been responsibly involved in this matter necessary for the development of society, also with obvious implications. Mining and minerals processing activities have changed the dynamic of the evolution of spaces that are in relative balance. As a result, geomorphological elements will modify, new superficial formations are created and their physical-chemical processes are accelerated.
In the Deva-Hunedoara metropolitan area, three main types of dumps can be distinguished, classified by the origin and characteristics of the dumper material:

- 41 waste dumps, resulting from uncovering or digging underground galleries located in close proximity to areas of extraction (Căoi Vețel village, Valea Banii -Ghelari village) (Fig. 1 and 2);

- 2 slag dumps, that of Buituri located in northern part of Hunedoara City, on the right side of Cerna, the north-eastern extremity of the steel platform, namely that of Călan, 


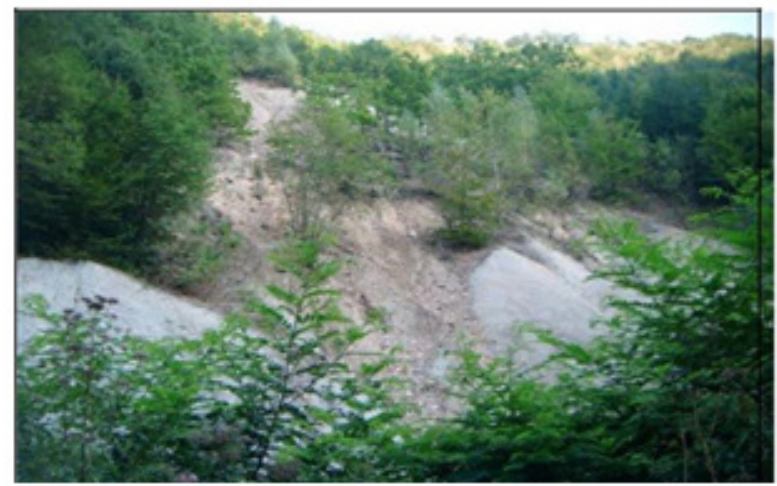

Fig. 1. Waste dump deposit from the former copper mine of Căoi (Veţel village)

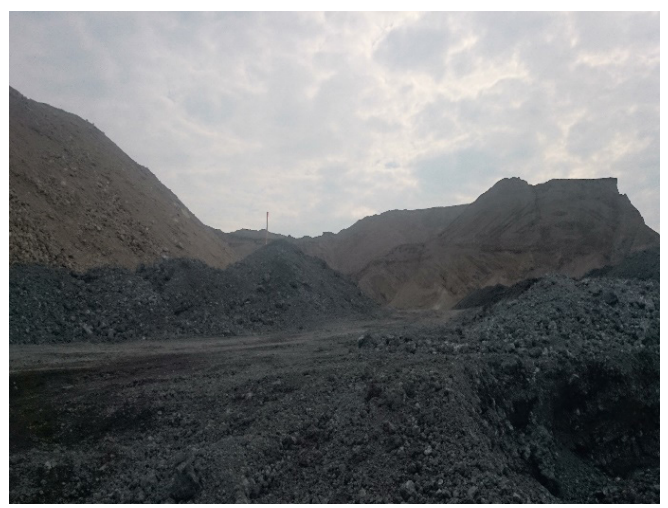

Fig.3. Slag dump deposit from Buituri

located in the flank of Perilor Hill, in the southwest industrial platform (Fig. 3 and 4);

- 3 career dumps:

\begin{tabular}{cccc}
\hline No. The economic unit & $\begin{array}{c}\text { The name of } \\
\text { techno structure }\end{array}$ & $\begin{array}{c}\text { Technical } \\
\text { status }\end{array}$ \\
\hline 1 & $\begin{array}{c}\text { S.C. Talc-Dolomita } \\
\text { S.A. Zlaști }\end{array}$ & $\begin{array}{c}\text { Valea Nădrabului } \\
\text { Dump }\end{array}$ & Active \\
\hline 2 & $\begin{array}{c}\text { S.C. Talc-Dolomita } \\
\text { S.A. Zlaști }\end{array}$ & $\begin{array}{c}\text { Zlaşti Career } \\
\text { Dump }\end{array}$ & Active \\
\hline 3 & $\begin{array}{c}\text { S.C. Talc-Dolomita } \\
\text { S.A. Zlaști }\end{array}$ & Teliuc III Dump & Active \\
\hline
\end{tabular}

\section{BACKGROUND}

Hazards in mining areas can be classified into two main categories:

- hazards triggered by human activity: explosions in the mine galleries (USS in 1947, Romania: Vulcan in 2001, 2006 and 2010 Petrila);

- hazards triggered by natural factors: breakage or slippage of tailings dams caused by earth-

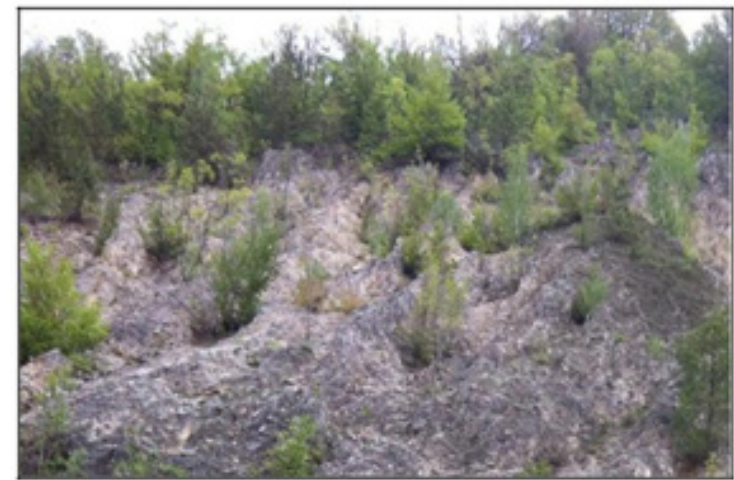

Fig. 2. Waste dump deposit from Valea Banii (Ghelari village)

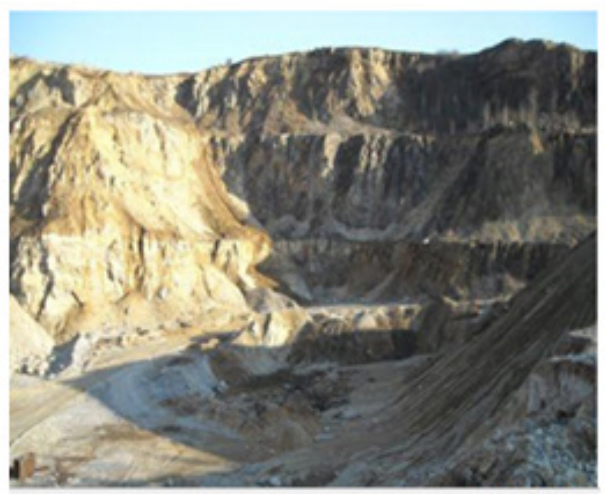

Fig. 4. Slag dump of the career center Teliuc III

quakes (Chile in 1965, the Philippines in 1996 etc.) and rainfall (United Kingdom in 1966, USA in 1972, Italy in 1985, China in 1988, South Africa in 1994, Indonesia in 2000, Hungary in 2010, Canada in 2014).

The long and intense mining activity in the county of Hunedoara was not without sporadic manifestation of hazards. Faulty location of landfills, upstream of human settlements and ignoring technical elements of construction by overfilling, above the maximum designed, have led to spills of slurry ponds or breaking over the crest slopes, Fig.5. (Bălă, 2005; Bălă, 2007).

In general, considering the small values of displacements, to record these displacements is used high precision geometric levelling and the measurement processing is performed by rigorous methods using functional models from conditioned measurements and from indirect measurements. (Sălăgean et al., 2015; Sestraș et al., 2015) 


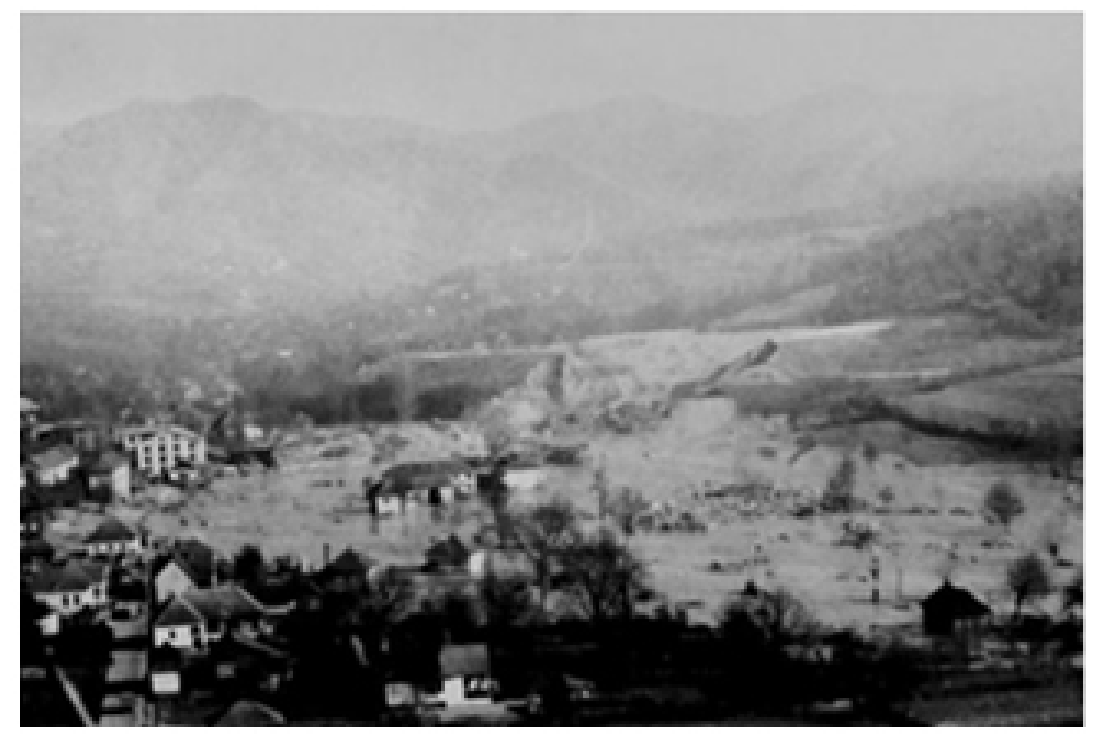

Fig. 5. Breaking of the tailings dam of the Certeju de Sus (source: www.adevărul)

The purpose of the scientific research detailed in this paper comprises in monitoring the slag dump from Buituri, Hunedoara County using space geodetic technology. Slag dump is the result of steel production activities carried out under the steel factory Arcelor Mittal Hunedoara S.A., formerly known as the steel factory Hunedoara Siderurgica S.A.

Therefore it was decided to conduct monthly topographic measurements to monitor possible dynamic changes that may appear in the context of continuous exploitation of the above mentioned slag dump.

In many cases, to ensure the stability of the area, both during the exploitation activity and its cessation, it must be known the direction of action and intensity of deformation processes and the displacement of rocks. (Farcaș et al., 2015)

In processing the geodetic observations, based on the type of measurements made, are used mathematical models appropriate for indirect measurements and conditioned measurements of same precision or of different precision. (Ortelecan et al., 2014; Vele et al., 2014)

As a result of extracting a volume of useful minerals from a deposit, the state of stress and strain from the massif changes the form. This has the effect of destroying the stability of surrounding rocks, so fractured rocks from the excavation contour are set in motion. (Sălăgean et al., 2016)

\section{MATERIALS AND METHODS}

The perimeter occupied by the slag dump (Fig. 6) serves as a storage area for over 30 million cubic meters of blast furnace and steelworks slag. Currently, the landfill is exploited for slag, bark of cast iron and other ferrous debris.

Therefore it was decided to conduct monthly topographic measurements to monitor possible dynamic changes that may appear in the context of continuous exploitation of the above mentioned slag dump.

An initial number of eighteen points that are subject to monitoring has been imposed. Because of the fact that most of the geodetic benchmarks have been destroyed, due to meteorological conditions or continuous operations carried out in the slag dump, only six points on the site of the operation of the company SC SLAG PROCESSING SA HUNEDOARA have been monitored. The topographic works started in 2011 (Fig. 7); in 2016 the aim is to determine the displacements of five points staked out by concrete benchmarks.

Topographic measurements were realized using South S82 GNSS Rover (Fig. 8) together with Carlson SurvCE software for the processing stage. In order to accomplish the monitoring of the slag dump, measurements were effected by stationing in each of the five points. Once the GPS was installed on the point whose coordinates are to be determined, the required settings have been 


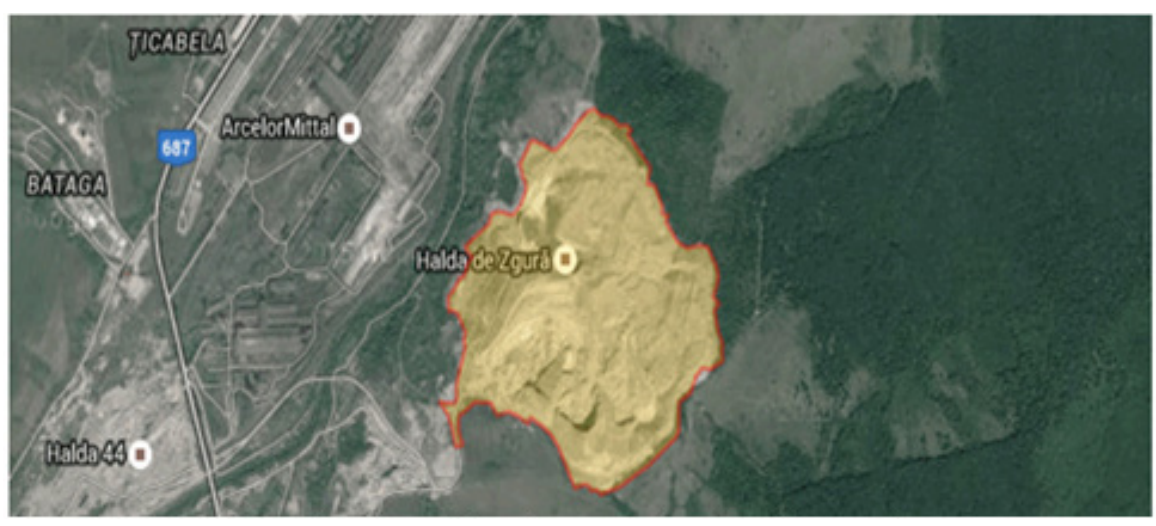

Fig. 6. Slag dump location near the city of Hunedoara

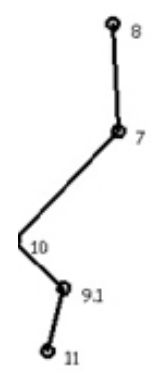

\begin{tabular}{|c|c|c|c|}
\hline \multicolumn{4}{|c}{ The Coordinate Inventorv } \\
Stereographic Projection 1970 \\
\hline \multicolumn{4}{|c}{20.05 .2011} \\
\hline Pct. & $\mathrm{E}(\mathrm{m})$ & $\mathrm{N}(\mathrm{m})$ & Cota \\
\hline 2 & 339543.679 & 477795.161 & 365.710 \\
\hline 8 & 339036.765 & 478149.827 & 264.790 \\
\hline 7 & 339040.346 & 478074.348 & 273.605 \\
\hline 10 & 338966.407 & 477997.117 & 265.726 \\
\hline 9.1 & 339001.889 & 477963.618 & $275.04 \mathrm{C}$ \\
\hline 11 & 338990.395 & 477919.455 & 279.096 \\
\hline
\end{tabular}

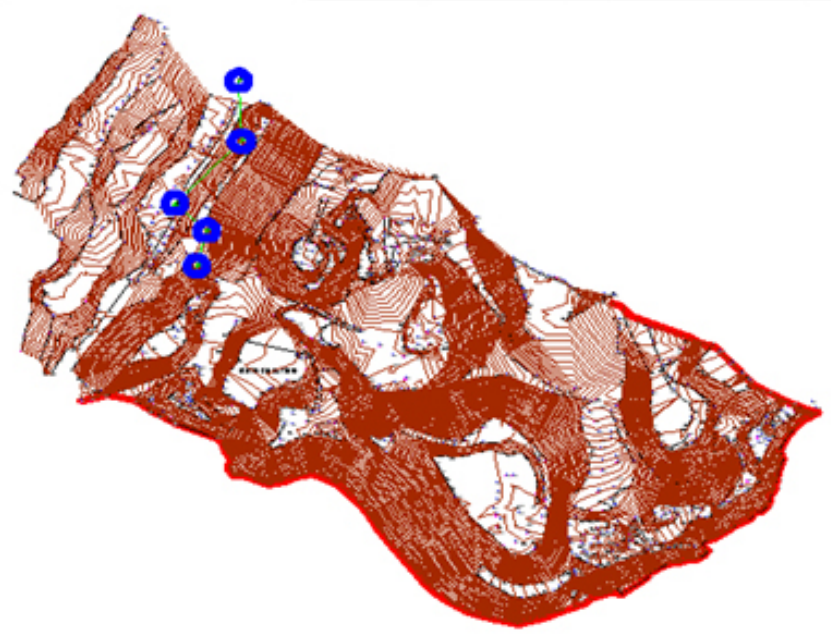

Fig. 7. Sketch of the network points and measurement zero

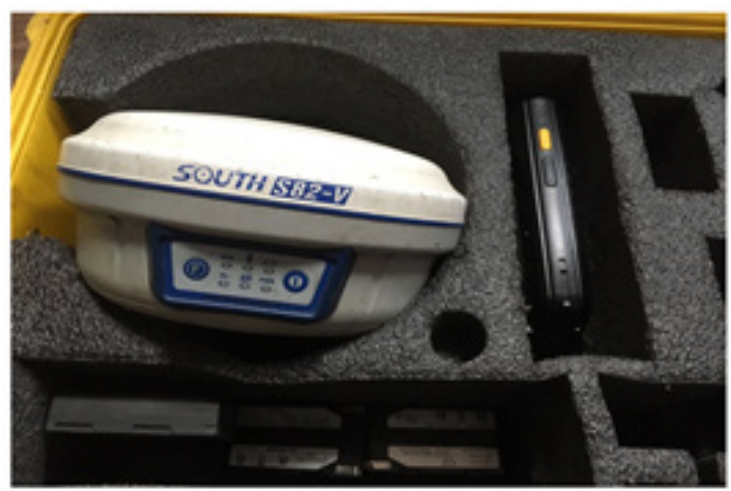

Fig. 8. South S82-V GNSS Rover 
performed and then, the operator had to proceed to the measurement process.

\section{RESULTS AND DISCUSSIONS}

Monitoring possible movements is performed by comparing transversal and longitudinal profiles drawn based on zero measurement carried out on 20.05.2011, with the ones obtained after processing of the monthly measurements realized throughout the years 2011, 2012, 2013, 2014, 2015 and 2016. Also, for observing the displacements, comparative charts or tables with records regarding coordinates differences are studied.

The results obtained from processing these measurements can be observed in the graphical tables shown below (tab. 1).

The first step for creating the 3D model is importing the surveyed points and drawing them into the CAD environment. For instance, when using AutoCAD software, ProfLT and TopoLP can be used to achieve longitudinal profiles and cross sections (Fig. 11 and 12).

Based on the cycles of measurements realized for the studied objective, the following conclusions emerge:

- the maximum horizontal and vertical displacements have been recorded for points 9 and 11 because they were destroyed in 2014 and then replaced;

- maximum height differences a have been recorded for points 9 and 11 for the same reason mentioned above;

- by comparing the values of the determined displacements with the attention and alarm values, these values do not fall within the normal tolerances accepted for the phenome-

Tab. 1. Height differences, expressed in millimetres, recorded year on year starting with measurement zero

\begin{tabular}{ccccccc}
\hline $\begin{array}{c}\text { No. } \\
\text { point }\end{array}$ & $\begin{array}{c}\text { Measurement } \\
\text { zero 20.05.2011 }\end{array}$ & $\begin{array}{c}\text { Measurement } \\
17.09 .2012\end{array}$ & $\begin{array}{c}\text { Measurement } \\
16.09 .2013\end{array}$ & $\begin{array}{c}\text { Measurement } \\
19.09 .2014\end{array}$ & $\begin{array}{c}\text { Measurement } \\
15.09 .2015\end{array}$ & $\begin{array}{c}\text { Measurement } \\
14.01 .2016\end{array}$ \\
\hline 2 & 477795.161 & 0 & & \multicolumn{2}{c}{ no longer follows } & \\
\hline 8 & 478149.827 & -0.002 & 0.02 & 0.039 & 0.078 & 0.027 \\
\hline 7 & 478074.348 & -0.006 & -0.023 & 0.001 & 0.029 & -0.028 \\
\hline 10 & 477997.117 & -0.331 & -0.343 & -0.317 & -0.382 & -0.31 \\
\hline 9.1 & 477958.618 & -4.949 & -4.965 & -13.353 & -13.29 & -13.382 \\
\hline 11 & 477919.455 & 0.167 & 0.166 & -47.994 & 12.012 & -48.035 \\
\hline
\end{tabular}

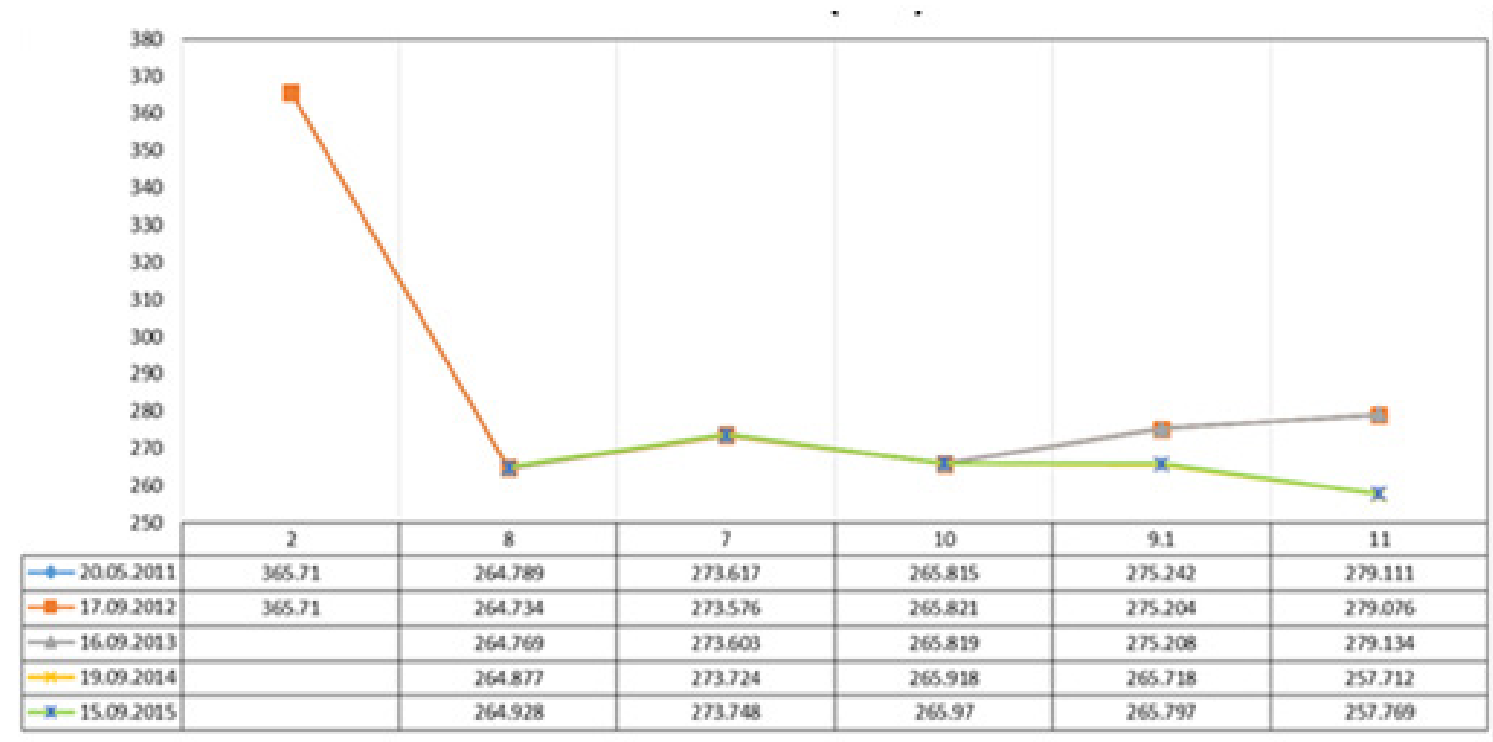

Fig. 9. Evolution of the height values of the network points starting with measurement zero 


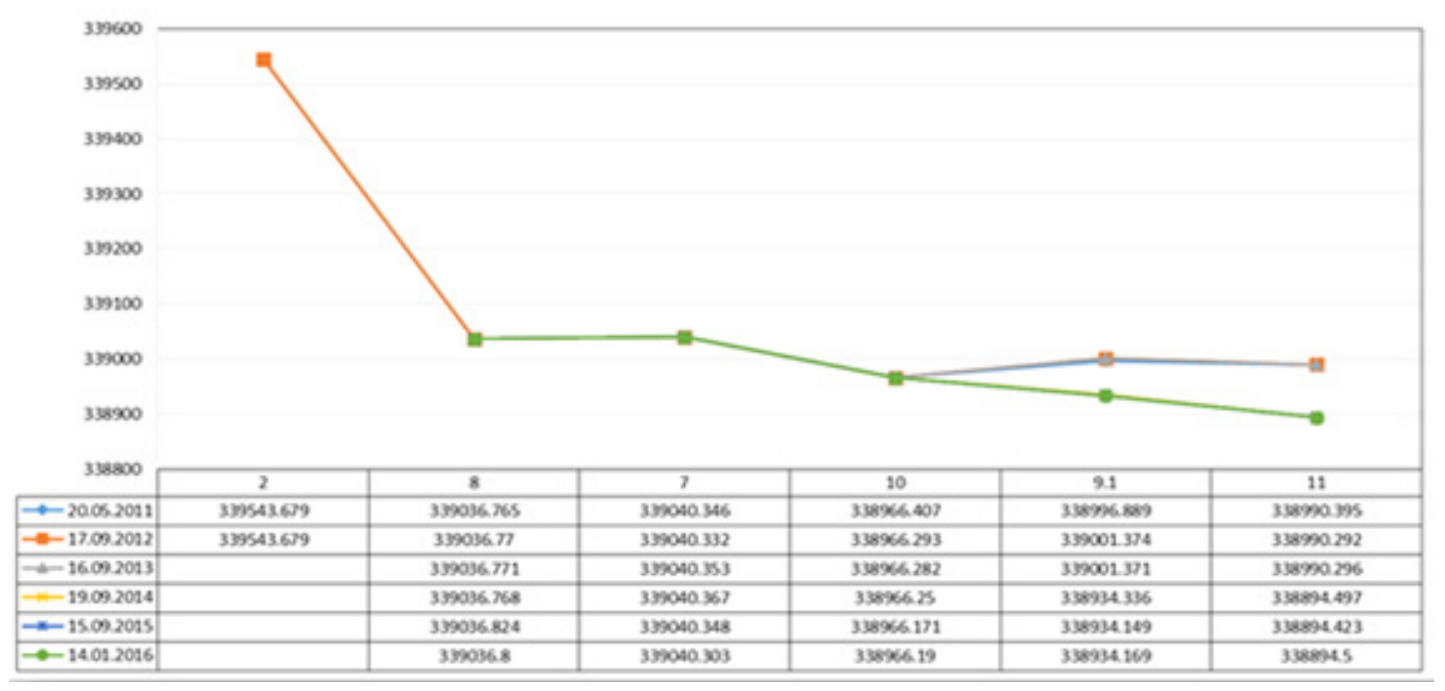

Fig. 10. Evolution of horizontal displacements of network points starting with measurement zero

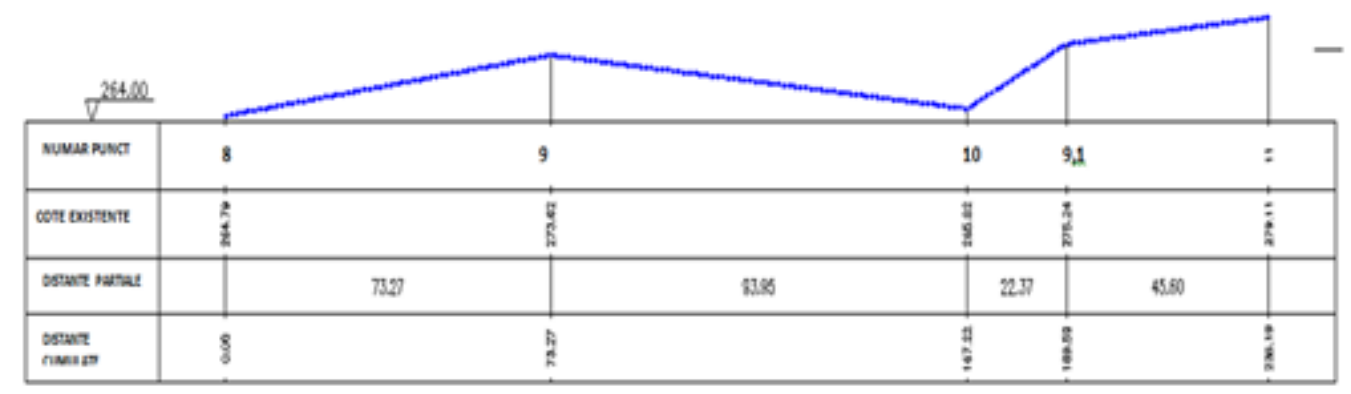

Fig. 11. Transverse profile obtained for measurements realized in 16.01.2011

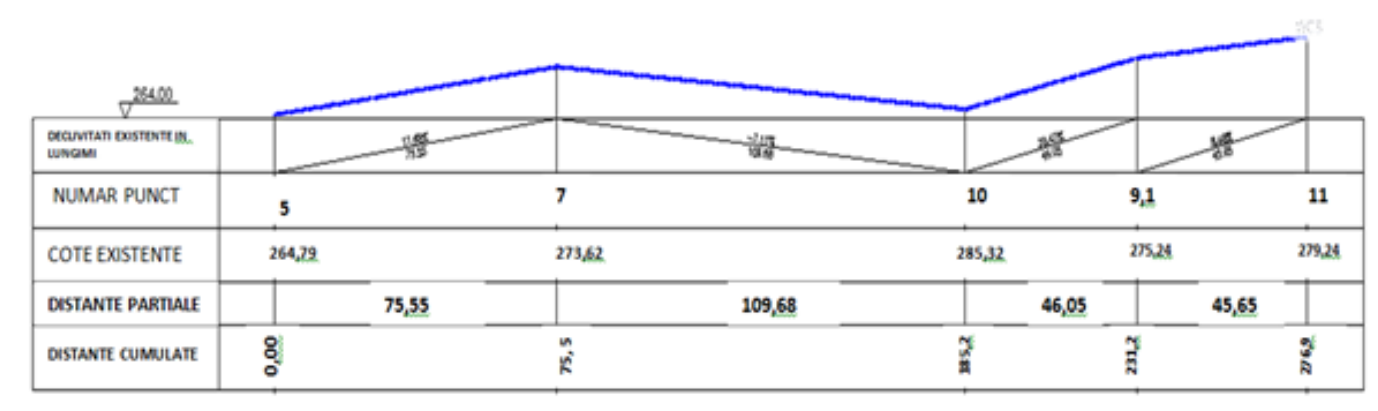

Fig. 12. Longitudinal profile obtained for measurements realized in 16.01.2011

non of settlement, leading to the conclusion that the dump represents a danger to the surrounding areas.

\section{CONCLUSION}

Movements and changes in the structure of the slag dump have been determined as the result of the monthly study realized upon the benchmarks installed in the perimeter of interest. Due to modernization of techniques and technologies in the field of engineering geodetic, observations of the movements of a structure are permitted using modern surveying techniques and tools.

An eloquent example is represented by the case of the slag dump from Buituri, Hunedoara County presented in the present scientific research, as geodetic satellite technology application facilitates monthly measurements. Considering that 
exploring the area under study is difficult, as the dump is being constantly exploited, the GPS receiver represents the optimal convenient solution.(Bălă, 2006)

The number of points collected in a short interval of time is very high, enabling the correct interpretation of the results.

The issue of measuring and graphic representation of settlements, horizontal linear movements and landslides for structures such as slag or sterile dumps, requires further studies and interdisciplinary research, creating links between specialists in the fields of terrestrial measurements science and geology.

\section{REFERENCES}

1. Bălă A (2005). Modern technologies used for monitoring methods for the movements of surfaces located in mining areas. RevCAD Journal of Geodesy and Cadastre, Vol. 5.

2. Bălă A (2006). The GPS Reference Station Solution to the Future. Bulletin of the "Politehnica" University of Timisoara.

3. Bălă A (2007). Considerations on Custom Measurement Methods to Study the Formation and Movement of Land and Construction of Surface Mining E.M.Petrila. RevCAD Journal of Geodesy and Cadastre, Vol. 7.

4. Farcaş R, Sălăgean T, Poruţiu AR, Ortelecan M, Onose D, Savu A, Naș S, Călin M (2015). General Aspects Regarding the Present Situation of Areas Affected by Subsidence
Produced by Exploitation of Rock Salt by Dissolving. Agriculture - science and practice 1-2(93-94):166-169.

5. Joldiș R (2013). Research on technologies G.I.S. monitoring erosion degraded lands. PhD Thesis summary, University of Agricultural Sciences and Veterinary Medicine ClujNapoca.

6. Ortelecan M, Pop I, Sălăgean T, Sestraș P, Pop N (2014). Aspects Concerning the Processing of Observations in Support Networks Related to Hydropower Objectives. Bulletin UASVM Horticulture 71(2):437-444.

7. Sălăgean T, Onose D, Ortelecan $M$, Sestraș P, Vele D, Călin M, Farcaș R (2015). Aspects Regarding the Observations of Vertical Displacements of Rockfill (Riprap) Dams. Scientific Papers. Series E. Land Reclamation, Earth Observation \& Surveying, Environmental Engineering. vol. IV:165-170.

8. Sălăgean T, Rusu T, Onose D, Farcaș R, Duda B, Sestraș P (2016). The Use of Laser Scanning Technology in Land Monitoring of Mining Areas. Carpathian Journal of Earth and Environmental Sciences, Vol. 11, No 2: 565-573.

9. Sestraș P, Sălăgean T, Dîrja M, Ortelecan M, Vele D, Ficior D, Deak J (2015). Aspects Regarding the Use of Topographic Measurements for Monitoring Drăgan Valley Dam. Bulletin UASVM Horticulture 72(2):530-536.

10. Vele D, Pop I, Ortelecan M, Sălăgean T (2014). Aspects Regarding the Monitoring of Weight Dams by Geodetic Measurements. RevCAD Journal of Geodesy and Cadastre 17:161-168.

11. ${ }^{* * *}$ www.arcelormittalhunedoara.ro;

12. ${ }^{* * *}$ www.topolt.ro. 